
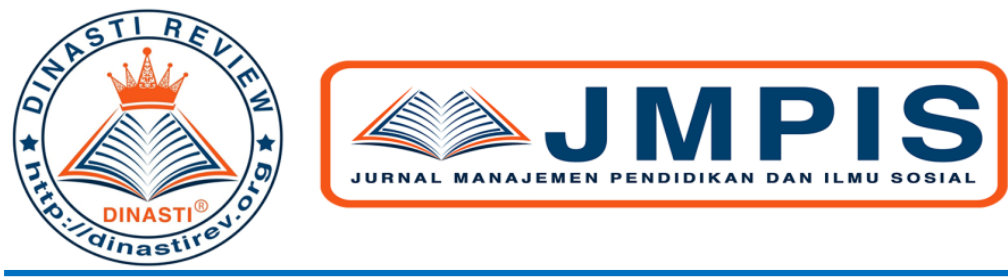

$+6281387654578$

+6281387654578 (Q)

https://dinastirev.org/JMPIS (7)

dinasti-info@gmail.com (G)

\title{
ANALISIS SURVEI KEPUASAN MASYARAKAT PADA PELAYANAN PERIJINAN DI DINAS PENANAMAN MODAL DAN PELAYANAN TERPADU SATU PINTU (DPMPTSP) KABUPATEN KEPULAUAN TALAUD
}

\section{Stenly Rini Larono ${ }^{1}$}

1) Universitas Terbuka-2020, Manado, Indonesia

\begin{tabular}{|c|c|}
\hline $\begin{array}{c}\text { ARTICLE INFORMATION } \\
\text { Received: } 25 \text { April } 2020 \\
\text { Revised: } 2 \text { Mei } 2020 \\
\text { Issued: } 8 \text { Mei } 2020 \\
\text { Corresponding Author: First } \\
\text { author } \\
\text { E-mail: } \\
\text { jurry1303@gmail.com }\end{array}$ & $\begin{array}{l}\text { Abstrak: Pengukuran Indeks Kepuasan Masyarakat } \\
\text { adalah untuk menentukan perkembangan kinerja unit } \\
\text { dalam layanan lembaga pemerintah yang dilaksanakan } \\
\text { oleh lembaga terkait secara berkala dan dapat digunakan } \\
\text { sebagai bahan untuk kebijakan mereka sendiri untuk } \\
\text { lebih meningkatkan kualitas layanan publik. Sedangkan } \\
\text { tujuan penelitian mengukur IKM: bagaimana tingkat } \\
\text { kepuasan pelanggan, mengetahui unsur-unsur yang } \\
\text { harus ditingkatkan dan bagaimana cara meningkatkan } \\
\text { kepuasan masyarakat. Indikator Pengukuran Kepuasan } \\
\text { Masyarakat oleh PermenpanRB No. 14 tahun } 2017 \\
\text { adalah Persyarataan, Sistem mekanisme dan Prosedur, } \\
\text { Waktu Penyelesaian, Biaya/tarif, Produk spesifikasi } \\
\text { jenis pelayanan, Kompetensi pelaksana, Perilaku } \\
\text { pelaksana, Sarana dan prasarana serta Penanganan } \\
\text { pengaduan, saran, dan masukan. Berdasarkan indikator } \\
\text { pengukuran kepuasan publik di Dinas Penanaman } \\
\text { Modal dan Pelayanan Terpadu Satu Pintu (DPMPTSP) } \\
\text { di Kabupaten Kepulauan Talaud, Penulis } \\
\text { merekomendasikan sebagai berikut: (1) memberikan } \\
\text { pelatihan kepada petugas loket pendaftaran pada unit } \\
\text { penelitian administrasi yang berkaitan dengan } \\
\text { pelayanan; dan (2) menyebarkan dan menyiapkan } \\
\text { brosur atau leaflet di loket pendaftaran survey IKMakan } \\
\text { terus dilakukan secara berkesinambungan } \\
\text { Kata Kunci: Survei, Kepuasan,Masyarakat, Pelatihan }\end{array}$ \\
\hline
\end{tabular}

\section{PENDAHULUAN}

Seiring dengan kemajuan teknologi dan tuntutan masyarakat dalam hal pelayanan , maka unit penyelenggara pelayanan publik. Khususnya Dinas Penanaman Modal dan Pelayanan Terpadu Satu Pintu dituntut untuk memenuhi harapan masyarakat dalam melakukan pelayanan .pelayanan yang baik serta memenuhi harapan masyarakat dalam memenuhi harapan akan menghasilkan kepuasan bagi pengguna layanan. 
Dalam rangka akuntabilitas pelayanan publik, pemerintah telah mengeluarkan mengeluarkan kebijakan pendayagunaan aparatur Negara bidang pelayanan publik melalui Keputusan Menteri Negara Pendayagunaan Aparatur Negara dan Repormasi Birokrasi (PERMENPANRB) Nomor 14 Tahun 2017 tentang Pedoman Survey Kepuasan Masyarakat terhadap penyelenggaraan pelayanan publik.

Survey kepuasan masyarakat merupakan salah satu upaya yang harus dilakukan dalam usaha memperbaiki pelayanan publik. Survey ini dapat mengukur sejauh mana kualitas pelayanan penyelenggara layanan publik serta dapat dijadikan referensi dalam melakukan penetapan proiritas perbaikan layanan.

Sejak diterapkannya UU Nomor 32 tahun 2004 yang kemudian telah diperbaharui dengan UU Nomor 23 Tahun 2014 tentang Pemerintahan Daerah yang memudahkan daerah untuk mengurus daerahnya masing-masing membawa dampak pada peningkatan iklim investasi di daerah. Namun hal ini tetap membawa berbagai hambatan investasi yang digelar didaerah, dan terwujud dalam berbagai bentuk: dari kebijakan pajak dan retribusi daerah sampai ke pungutan liar, dari ketidakpastian biaya dan waktu sampai ke uang pelicin. Sebagai akibatnya, dalam konteks investasi, kebijakan otonomi daerah diyakini banyak pihak justru telah menimbulkan efek yang menurunkan tingkat kegiatan investasi, dan pada akhirnya kemudian mengurangi daya tarik investasi di daerah. Hal ini apabila dibiarkan terus akan membawa kondisi investasi di daerah pada tahap "cukup memprihatinkan".

Pemerintah berusaha untuk memperbaiki iklim penanaman modal di daerah dengan merumuskan salah satu kebijakan terkait dengan kepentingan tersebut, yaitu penerapan sistem Pelayanan Terpadu Satu Pintu (PTSP) yang didasarkan pada UU No. 25/2007 tentang Penanaman Modal. Pola pelayanan terpadu satu pintu diselenggarakan pada satu tempat yang meliputi berbagai jenis pelayanan yang memiliki keterkaitan proses dan dilayani melalui satu pintu.

Kebijakan sistem PTSP dapat saja sebagai alternatif perbaikan dari Sistem Pelayanan Satu Atap. Namun demikian, sistem baru ini tidak akan memberikan perubahan yang diharapkan, jika tidak dapat menunjukan adanya efisien dalam pelayanan, memiliki standar waktu dan biaya yang jelas, memiliki prosedur pelayanan yang sederhana, dan mudah diakses oleh yang membutuhkan. Untuk mewujudkan sistem pelayanan administrasi penanaman modal, PTSP memiliki strategi yang perlu dikembangkan melalui pembentukan Unit Pelayanan (UP) yang memiliki kewenangan khusus dalam pemberian perizinan bidang penanaman modal. publik berupa alat transportasi yang dapat memenuhi standar pelayanan minimal dalam angkutan umum. Penerapan sistem angkutan umum yang cepat dan efisien sehingga masyarakat lebih tertarik dengan angkutan umum. Upaya tersebut dapat menekan kenaikan jumlah kendaraan pribadi.

Kebijakan sistem PTSP ini juga dijalankan oleh Pemerintah Kabupaten Kepulauan Talaud untuk meningkatkan kinerja pelayanan publik. Pelayanan perijinan terpadu ini diharapkan mampu mengatasi berbagai macam permasalahan dalam penyelenggaraan pelayanan perijinan di Kabupaten KepulauanTalaud. Penerapan OSS (One Stop Service) diharapkan menjadi salah satu daya tarik investasi, karena dalam OSS terjadi pemangkasan 
birokrasi, sehingga proses yang semula berbelit-belit menjadi lebih pendek. Untuk Kabupaten Kepulauan Talaud pengembangan dan penyelenggaraan One Stop Service diimplementasikan dengan dibentuknya Dinas Penanaman Modal dan Pelayanan Terpadu Satu Pintu (DPMPTSP).

Dalam perjalanannya, pergerakan iklim investasi dan penanaman modal tidak didukung dengan penyelenggaraan pelayanan perizinan di Kabupaten Kepulauan Talaud yang dinilai masih menemui beberapa kendala. Permasalahan pertama, persediaan sumber daya manusia (SDM) yang masih kurang secara kuantitas dimana pada DPMPTSP Kabupaten Kepulauan Talaud yang tersedia ada 27 orang, sedangkan jumlah pemohon perijinan dari tahun ke tahun mengalami peningkatan.

Permasalahan kedua, dengan jumlah SDM (kelompok fungsional) yang tersedia pada DPMPTSP Kabupaten Kepulauan Talaud yang berada di Front Office (FO) dan Back Office (BO) hanya sebanyak 1 Orang. Hal ini tentu bisa menimbulkan permasalahan bagi pemohon perijinan seperti yang diungkapkan oleh seorang Staf front office Bagian Penanaman Modal Sub Bidang Bagian Promosi, Pendaftaran, Data Dan Pengembangan BPMPPTSP Kabupaten Semarang yang mengatakatan bahwa keterlambatan penyelesaian berkas perijinan bisa saja terjadi apabila terjadi penumpukan berkas pemohon perizinan yang belum diolah akibat kurangnya SDM pada DPMPTSP Kabupaten Kepulauan Talaud, apalagi terdapat beberapa jenis perijinan yang memerlukan kunjungan lapangan.

Permasalahan ketiga, berdasarkan hasil wawarncara dengan Ketua Bidang Penanaman Modal Badan Penanaman Modal dan Pelayanan Perizinan Terpadu Satu Pintu (DPMPTSP) Kabupaten Kepulauan Talaud yang sering menjadi kendala dalam penyelenggaraan pelayanan perizinan dan penanaman modal di BPMPPTSP Kabupaten Semarang adalah terkait dengan pengadaan sarana dan prasarana yang dinilai belum memadai.

Kondisi-kondisi seperti inilah yang menyebabkan penyelenggaraan pelayanan di Dinas Penanaman Modal dan Pelayanan Perizinan Terpadu Satu Pintu (DPMPTSP) Kabupaten Kepulauan Talaud belum dapat berjalan secara prima.

Hal yang paling esensial dalam peningkatan kualitas pelayanan adalah adanya kesetaraan hubungan antara masyarakat pengguna jasa dengan aparat yang bertugas memberikan jasa pelayanan. Pelayanan publik hanya akan menjadi baik atau berkualitas apabila masyarakat yang mengurus suatu jenis pelayanan tertentu mempunyai posisi tawar yang sebanding dengan posisi tawar petugas pemberi pelayanan (Ratminto, 2008:36).

Tujuan Penelitian

1. Untuk mengkaji bagaimana tingkat kepuasan pelanggan terhadap pelayanan di Dinas Penanaman Modal dan Pelayanan Terpadu Satu Pintu (DPMPTSP) Kabupaten Kepulauan Talaud

2. Untuk mengetahui unsur-unsur apa saja yang harus ditingkatkan pada Dinas Penanaman Modal dan Pelayanan Terpadu Satu Pintu (DPMPTSP) Kabupaten Kepulauan Talaud. 
3. Untuk menganalisis bagaimana cara meningkatkan kepuasan masyarakat terhadap pelayanan di Dinas Penanaman Modal dan Pelayanan Terpadu Satu Pintu (DPMPTSP) Kabupaten Kepulauan Talaud.

\section{KAJIAN PUSTAKA}

\section{Teori Administrasi Publik}

Administrasi publik adalah suatu kombinasi yang kompleks antara teori dan praktek, dengan tujuan mempromosikan pemahaman terhadap pemerintah dalam hubungannya dengan masyarakat yang diperintah, dan juga mendorong kebijakan publik agar lebih responsif terhadap kebutuhan sosial.

Muncul paradigma baru bernama "The New Public Service" oleh J.V Denhardt dan R.B. Denhardt (2003) (dalam Pasolong, 2007:35). Keduanya menyarankan untuk meninggalkan prinsip admininstrasi klasik dan reinventing Government atau New Public Management. Prinsip NPS : (dalam Keban, 2008:37)

1. Melayani masyarakat bukan pelanggan (serve citizen, not customers)

2. Mengutamakan kepentingan publik (seek the public interest)

3. Lebih menghargai warga negara daripada kewirausahaan (value citizenship over entrepreneurship)

4. Berfikir strategis dan bertindak demokratis (think strategically, act democratically)

5. Menyadari bahwa akuntabilitas bukan merupakan suatu yang mudah (recognize that accountability is not simple)

6. Melayani daripada mengendalikan (serve rather than steer), dan

7. Menghargai orang, bukannya produktivitas semata (value people, not just productivity)

\section{Teori Pelayanan Publik}

Menurut Martin Cole and Greg Parston (2006: 6), mendefinisikan pelayanan publik adalah inklusif yang mencakup semua organisasi yang terlibat dalam memberikan pelayanan kepada masyarakat, yang setidaknya sebagian dari organisasi menarifkan uang untuk digunakan dalam membayar pajak. Organisasi pelayanan publik itu termasuk instansi pemerintah, organisasi nirlaba dan perusahaan swasta yang menyediakan layanan.

Definisi Maxwell (dalam Ismail, dkk, 2010:21) tentang enam dimensi kunci kualitas (1984), dikembangkan dalam hubungan pelayanan yang sehat, memberikan petunjuk awal yang baik, untuk menyertakan kemauan konsumen. Dikemukakan bahwa layanan harus: a) Appropiate and relevan (sesuai dan relevan) untuk memenuhi pilihan individu atau kelompok yang sesuai dengan harapan dan kesukannya. b) Available and accesible (tersedia dan dapat dimiliki) untuk semua orang atau untuk individu atau kelompok yang diberi prioritas lebih. c) Equitable (keadilan) mempunyai persamaan dalam perlakuan bagi individu atau kelompok dalam masyarakat dalam kondisi yang sama. d) Acceptable (dapat diterima) dalam hubungan kualitas layanan yang diberikan, cara pemberianny. Kriteria ini termasuk sejumlah kriteria lain, yaitu dapat menyentuh sesuai yang diinginkan, menyenangkan, mudah digunakan, dapat dipercaya, tepat waktu, peka dan manusiawi. e) Economic dan efficient (ekonomis dan efisien) dari sudut pengguna layanan, yaitu mereka membayar layanan melalui pajak oleh masyarakat. f) Effective (efektif), memberi keuntungan bagi pengguna dan masyarakat.

\section{Teori Kepuasan Pelanggan}


Kepuasan Pelayanan menurut PermenpanRB nomor 14 Tahun 2017 adalah hasil pendapat atau penilaian masyarakat terhadap kinerja pelayanan yang akan diberikan aparatur penyelenggara pelayanan publik. Sedangkan Indeks Kepuasan Masyarakat (IKM) adalah data atau informasi tentang tingkat kepuasan masyarakat yang diperoleh dari hasil pengukuran secara kuantitatif dan kualitatif atas pendapat masyarakat dalam memperoleh pelayanan dari aparatur penyelenggara pelayanan publik dengan membandingkan antara harapan dan kebutuhannya. Indikator Pengukuran Kepuasan Masyarakat (IKM) menurut PermenpanRB nomor 14 tahun 2017 adalah Persyarataan, Sistem mekanisme dan Prosedur, Waktu Penyelesaian, Biaya/tarif, Produk spesifikasi jenis pelayanan, Kompetensi pelaksana, Perilaku pelaksana, Sarana dan prasarana serta Penanganan pengaduan, saran, dan masukan.

\section{Hubungan Kualitas Pelayanan dengan Kepuasan Pelanggan}

Kualitas layanan bisa diartikan sebagai "ukuran seberapa bagus tingkat layanan yang diberikan mampu sesuai dengan ekspetasi pelanggan" (Lewis\&Booms dalam Tjiptono, 2008:85). Menurut zeithhaml-Parasurman- Berry (dalam Harbani Pasolong, 2007:135), untuk mengetahui kualitas pelayanan yang dirasakan secara nyata oleh konsumen, ada indikator ukuran kepuasan konsumen yang terletak pada lima dimensi kualitas pelayanan menurut apa yang dikatakan konsumen yaitu : 1. Tangibles 2. Reliability 3. Responssiveness 4. Assurance 5. Empathy Teori "The triangle of balance in service quality " menurut Morgan dan Murgatroyd, bahwa dalam menyediakan pelayanan yang terbaik perlu dipertahankan keseimbangan dari ketiga komponen yaitu Interpersonal Component, Procedure Environment / Process Component, and Technical / Professional Component untuk menghasilkan pelayanan yang berkualitas.

\section{Teori Peningkatan Kualitas Pelayanan}

Menurut Tjiptono teknik ini dikemukakan pertama kali oleh Martilla dan James pada tahun 1977 dalam artikel mereka "Importance Performance Analysis" yang dipublikasikan di Journal of Marketing. Pada teknik ini, responden diminta untuk menilai tingkat kepentingan berbagai atribut relevan dan tingkat kinerja perusahaan pada masing-masing atribut tersebut, kemudian nilai rata-rata tingkat kepentingan dan kinerja tersebut dianalisis pada ImportancePerformance Matrix. Matriks ini menunjukkan bidang atau atribut tertentu yang perlu dipertahankan dan aspek-aspek yang perlu dikurangi prioritasnya (Martilla dan James dalam Tjiptono, 2011:319-321).

\section{METODE PENELITIAN}

\section{Metode Survey}

Penelitian ini merupakan penelitian deskriptik kuantitatif, dimana datanya berupa angkaangka dan dianalis dengan tehnik analisis statistik deskriptik.Guna melengkapai hal analisis, disajukan juga analisis kuantitatif sebagai pelengkap. Populasi penelitian ini adalah mengambil sampel khususnya bagi pelaku usaha yang ada di 17 kecamatan di Kabupaten Kepulauan Talaud.

\section{Teknik Pengumpulan Data}


Data pada Penelitian ini diambil dengan instrumen berupa kuesioner dengan cara wawancara langsung dengan pelaku usaha.

\section{Variabel Pengukuran SKM}

Variabel pada pengukuran ini didasarkan pada Peraturan Menteri Pendayagunaan Aparatur Negara dan Repormasi Birokrasi Nomor 14 Tahun 2017 tentang Pedoman Survey Kepuasan Masyarakat Unit Penyelenggaraan Pelayanan publik yang terdiri dari 9 ruang lingkup yaitu :

\section{Persyaratan}

Persyaratan adalah syarat yang harus dipenuhi dalam pengurusan suatu jenis pelayanan, baik persyaratan teknis maupun administrative.

2. Sistem, Mekanisme dan Prosedur

Prosedur adalah tata cara pelayanan yang dilakukan bagi pemberi dan penerima pelayanan, termasuk pengaduan.

3. Waktu Penyelesaian

Waktu penyelesaian adalah jangka waktu yang diperlukan untuk menyelesaikan seluruh proses pelayanan dari setiap jenis pelayanan.

4. Biaya / Tarif

Biaya/Tarif adalah ongkos yang dikenakan kepada penerima layanan dari penyelenggara yang besarnya ditetapkan berdasarkan kesepakatan antara Penyelenggara dan masyarakat.

5. Produk Spesifikasi Jenis Pelayanan

Produk Spesifikasi Jenis Pelayanan adalah hasil pelayanan yang diberikan dan diterima sesuai dengan ketentuan yang telah ditetapkan.Produk pelayanan ini merupakan hasil dari setiap spesifikasi jenis pelayanan.

6. Kompetensi Pelaksana

Kompetensi Pelaksana adalah kemampuan yang harus dimiliki oleh pelaksana meliputi Pengetahuan, Keahlian, ketrampilan, dan pengalaman .

7. Perilaku Pelasana

Perilaku Pelasana adalah sikap petugas dalam memberikan pelayanan.

8. Sarana dan Prasarana

Sarana adalah segala sesuatu yang dapat dipakai sebagai alat dalam mencapai maksud dan tujuan. Prasarana adalah segala sesuatu yang merupakan penunjang utama terselenggaranya suatu proses (usaha, pembangunan, proyek ). Sarana digunakan untuk benda yang bergerak ( computer, mesin ) dan prasarana untuk benda yang tidak bergerak ( gedung).

9. Penanganan Pengaduan, Saran dan Masukan Penanganan Pengaduan, Saran dan Masukan, adalah tata cara pelaksanaanpenanganan pengaduan dan tindak lanjut.

\section{Teknik Analisis Data}

Analisis data pada pengukuran survey kepuasan masyarakat (SKM ) di Dinas Penanaman Modal dan Pelayanan Terpadu Satu Pintu ini digunakan analisis statistik 
deskriptik. Kesembilan ruang lingkup tersebut diatas, selanjutnya disusun ke dalam kuesioner dengan 9 item, dengan empat option jawaban. Adapun pensekorannya menggunakan skala likert, dengan skor 1 sampai dengan 4. Analisis selanjutnya mengkonversi ke dalam skala 100, dan kategorisasi mutu pelayanan/integritas di Penanaman Modal dan Pelayanan Terpadu Satu Pintu ditentukan sebagai berikut :

Tabel 1. Kategori Mutu Pelayanan

\begin{tabular}{llll}
\hline \multirow{2}{*}{ NO } & \multirow{2}{*}{ MUTU PELAYANAN } & \multicolumn{2}{c}{ NOMOR SKOR } \\
\cline { 3 - 4 } & & Skala 100 & Skala 1-4 \\
\hline 1 & A ( Sangat Baik ) & $81.26-100,00$ & $3,26-4,00$ \\
\hline 2 & B ( Baik ) & $62,51-81,25$ & $2,51-3,25$ \\
\hline 3 & C ( Kurang Baik) & $43,76-62,50$ & $1,76-2,50$ \\
\hline 4 & D ( Tidak Baik ) & $25,00-43,75$ & $1,00-1,75$ \\
\hline
\end{tabular}

Tabel 2. Responden Menurut Karakteristik Jenis Kelamin

\begin{tabular}{llll}
\hline No & Jenis Kelamin & Frekuensi & $\%$ \\
\hline 1 & Laki-laki & 139 & $60,70 \%$ \\
\hline 2 & Perempuan & 90 & $39,30 \%$ \\
\hline 3 & $\begin{array}{l}\text { Tidak mencantumkan } \\
\text { kelamin }\end{array}$ & 0 & $0 \%$ \\
Jumlah & & 229 & $100 \%$ \\
\hline
\end{tabular}

Berdasarkan table responden menurut karakteristik di atas mayoritas responden Pada penelitian ini berjenis kelamin laki-laki sebanyak 139 orang ( 60,70\%)

Tabel 3. Responden Menurut Karakteristik Pendidikan Terakhir

\begin{tabular}{llll}
\hline No & Pendidikan Terakhir & Frekuensi & $\%$ \\
\hline 1 & SD & 12 & $19,08 \%$ \\
\hline 2 & SMP & 49 & $21,37 \%$ \\
\hline 3 & SMA & 140 & $61,13 \%$ \\
\hline 4 & D3 & 1 & $0,43 \%$ \\
\hline 5 & S1 & 26 & $11,35 \%$ \\
\hline 6 & S2 & 0 & $0 \%$ \\
\hline & S3 mencantumkan & 1 & $0,43 \%$ \\
\hline Jumlah & pendidikan terakhir & 0 & $0 \%$ \\
\hline
\end{tabular}

Berdarkan table responden menurut karakteristik di atas mayoritas responden pada penelitian ini berpendidikan terakhir SLTA sebanyak 140 orang ( 61,13\%).

Tabel 4. Responden Menurut Karakteristik Pekerjaan Utama

\begin{tabular}{llll}
\hline No & Pekerjaan Utama & Frekuensi & $\%$ \\
\hline 1 & PNS & 5 & $2,18 \%$ \\
\hline 2 & TN1 & 0 & $0 \%$ \\
\hline 3 & POLRI & 0 & $0 \%$ \\
\hline 4 & SWASTA & 57 & $24,89 \%$ \\
\hline 5 & WIRASWASTA & 164 & $71,61 \%$ \\
\hline 6 & LAINNYA & 3 & $1,31 \%$ \\
\hline 8 & Tidak mencantumkan pekerjaan & 0 & $0 \%$ \\
\hline Jumlah & & 229 & $100 \%$ \\
\hline
\end{tabular}

Berdasarkan table responden menurut karakteristik diatas mayoritas responden pada penelitian ini berpekerjaan Wiraswasta sebanyak 164 orang $(71,61 \%)$. 


\section{HASIL DAN PEMBAHASAN}

\section{Hasil Penelitian}

Hasil Penyusunan Indeks Kepuasan Masyarakat (IKM) dari 229 (dua ratus dua puluh Sembilan) responden yang telah diminta pendapat mengenai pengalamannya dalam memperoleh pelayanan,maka analisa data yang telah dilakukan ( lihat lampiran) diketahui bahwa survey kepuasan masyarakat (SKM ) di Dinas Penanaman Modal dan Pelayanan Terpadu Satu Pintu sebesar 70,08 \% berada pada kategori "kurang baik" ( pada interval 65,00 $-76,60$. Hasil survey kepuasan masyarakat tersebut diatas, terdiri dari 9 ruang lingkup.Analisis selanjutnya adalah mendeskripsikan hasil analisis terhadap kesembilan ruang lingkup tersebut.

Tabel 5. Rata-rata Skor dan Peringkat pada Setiap Ruang Lingkup Pengukuran Indeks Kepuasan Pengguna Layanan Dinas Penanaman Modal dan Pelayanan Terpadu Satu Pintu

\begin{tabular}{ccccc}
\hline No & Ruang Lingkup & Rata-rata Skor & Kategori & Peringkat \\
\hline 1 & Persyaratan & 2,912 & Baik & 2 \\
\hline 2 & Sistem Mekanisme, Prosedur & 2,898 & Baik & 5 \\
\hline 3 & Waktu Penyelesaian & 2,771 & Baik & 7 \\
\hline 4 & Biaya/Tarif & Baik & 3 \\
\hline \multicolumn{5}{c}{ Produk Spesifikasi Jenis } \\
Pelayanan & 2,909 & Baik & 6 \\
\hline 6 & Kompetensi Pelaksana & Baik & 4 \\
\hline 7 & Perilaku Pelaksana & Baik & 1 \\
\hline 8 & Sarana dan Prasarana & 2,862 & Kurang Baik & 9 \\
\hline & Penanganan Pengaduan, Saran dan & 2,414 & Kurang Baik & 8 \\
\hline
\end{tabular}

1. Persyaratan

Persyaratan adalah syarat yang harus dipenuhi dalam pengurusan suatu jenis pelayanan, baik persyaratan teknis maupun administrative. Dari hasil analisis diperoleh Rata-rata skor sebesar 2,912 berada pada interval skor 2,51 s.d 3,25 kategori “ Baik “. Dengan demikian kepuasan masyarakat pengguna layanan di Dinas Penanaman Modal dan Pelayanan Terpadu Satu Pintu, ruang lingkup persyaratan berada pada kategori baik. Ruang lingkup persyaratan disajikan sebagai berikut :

Tabel 6. Ruang Liangkup : Persyaratan

\begin{tabular}{|c|c|c|c|c|}
\hline \multirow{2}{*}{ NO } & \multirow{2}{*}{ Jawaban } & \multirow{2}{*}{ Skor } & \multicolumn{2}{|c|}{ Frekuensi } \\
\hline & & & $\mathrm{F}$ & $\%$ \\
\hline 1 & Sangat Sesuai & 4 & 5 & $2.18 \%$ \\
\hline 2 & Sesuai & 3 & 14 & $6.11 \%$ \\
\hline 3 & Kurang Sesuai & 2 & 206 & $89.96 \%$ \\
\hline \multirow[t]{2}{*}{4} & Tidak Sesuai & 1 & 4 & $1.75 \%$ \\
\hline & & & 229 & $100.00 \%$ \\
\hline
\end{tabular}

Kesesuaian persyaratan pelayanan dengan jenis pelayanannya, nilai persentase tertinggi yaitu persepsi sesuaisebesar 89,96 persen, kemudian persespi kurang sesuai 6,11 persen, kemudian persepsi tidak sesuai 2,18 persen dan persepsi sangat sesuai 1, 75 persen.

2. Sistem Mekanisme dan Prosedur

Sistem Mekanisme dan Prosedur adalah tata cara pelayanan yang dikakukan bagi pemberi dan penerima layanan, termasuk pengaduan. Dari hasil analisis diperoleh Ratarata skor sebesar 2,898 berada pada interval skor 2,51 s.d 3,25 kategori "baik ". Dengan demikian 
Kepuasan masyarakat pengguna layanan Dinas Pdnanaman Modal dan Pelayanan Terpadu Satu Pintu, ruang lingkup Sistem mekanisme dan Prosedur berada pada kategori Baik.

Adapun hasil jawaban kuesioner kepuasan masyarakat pengguna layanan DPMPTSP Ruang lingkup Prosedur disajikan pada table berikut ini :

Tabel 7. Ruang Lingkup : Sistem Mekanisme dan Prosedur

\begin{tabular}{|c|c|c|c|c|}
\hline \multirow{2}{*}{ NO } & \multirow{2}{*}{ Jawaban } & \multirow{2}{*}{ Skor } & \multicolumn{2}{|r|}{ Frekuensi } \\
\hline & & & $\mathrm{F}$ & $\%$ \\
\hline 1 & Sangat Mudah & 4 & 5 & $2.18 \%$ \\
\hline 2 & Mudah & 3 & 20 & $8,73 \%$ \\
\hline 3 & Kurang Mudah & 2 & 197 & $86,03 \%$ \\
\hline 4 & Tidak Mudah & 1 & 7 & $3,06 \%$ \\
\hline \multicolumn{3}{|c|}{ Jumlah } & 229 & $100.00 \%$ \\
\hline
\end{tabular}

Kemudahan prosedur pelayanan di Dinas Penanaman Modal dan Pelayanan Terpadu Satu Pintu (DPM-PTSP), nilai tertinggi yaitu prosedurnya mudah sebesar 86,03 persen, kemudian prosedurnya kurang mudah 8,73 persen, prosedurnya sangat mudah 3,06 persen dan terakhir prosedurnya tidak mudah 2,18 persen.

3. Waktu Penyelesaian

Waktu penyelesaian adalah jangka waktu yang di perlukan untuk menyelesaikan seluruh proses pelayanan dari setiap jenis pelayanan. Dari hasil analisis diperoleh ratarata skor sebesar 2,771 berada pada interval skor 2,51 s.d 3,25 kategori " Baik " . Dengan demikian kepuasan masyarakat pengguna layanan DPM-PTSP, ruang lingkup waktu penyelesaian berada pada kategori baik.

Adapun hasil jawaban kuesioner kepuasan masyarakat pengguna layanan DPM-PTSP, ruang lingkup waktu penyelesaian disajikan pada tabel berikut ini :

Tabel 8. Ruang Lingkup : Waktu Penyelesaian

\begin{tabular}{clccr}
\hline \multirow{2}{*}{ NO Jawaban } & \multirow{2}{*}{ Skor } & \multicolumn{2}{c}{ Frekuensi } \\
\cline { 5 - 5 } & & 4 & 11 & \multicolumn{2}{c}{${ }^{2}$} \\
\hline 1 & Sangat Cepat & 3 & 37 & $16.16 \%$ \\
\hline 2 & Cepat & 2 & 175 & $76.42 \%$ \\
\hline 3 & Kurang Cepat & 6 & $2.62 \%$ \\
\hline 4 & Tidak Cepat & 1 & 229 & $100.00 \%$ \\
\hline
\end{tabular}

Kecepatan Waktu dalam Memberikan Pelayanan di Dinas Penanaman Modal dan

Pelayanan Terpadu Satu Pintu (DPM-PTSP), responden yang memilih cepat dalam memberikan pelayanan yaitu 76,42 persen, kurang cepatsebesar 16,16 persen, tidak cepat sebesar 4,80 persen dan sangat cepatsebesar 2,62 persen.

4. Biaya / Tarif

Pengertian Biaya/tarif menurut Permenpan RB Nomor 14 tahun 2017 adalah ongkos yang dikenakan kepada penerima layanan dalam mengurus dan/atau memperoleh pelayanan dari penyelenggara yang besarnya ditetapkan berdasarkan kesepakatan antara penyelenggara dan masyarakat. Dari hasil analisis yang diperoleh rata-rata skor 
sebesar 2,909 berada pada interval skor 2,51 s.d 3,25 kategori “ Baik “. Dengan demikian kepuasan masyarakat pengguna layanan DPM-PTSP, ruang lingkup biaya/tarif berada pada kategori baik. Biaya /Tarif yang dimaksud, ditetapkan berdasarkan Peraturan Daerah Nomor 10 Tahun 2012 tentang Retribusi Perizinan tertentu. Pada tahun 2017 dikeluarkan Peraturan Menteri Dalam Negeri Nomor 19 Tahun 2017 tentang Pencabutan Peraturan Menteri Dalam Negeri Republik Indonesia Nonor 22 Tahun 2016 tentang Perubahan atas Peraturan Menteri Dalam Negeri Nomor 27 Tahun 2009 tentang Pedoman

Adapun hasil jawaban kuesioner kepuasan masyarakat pengguna layanan DPM-PTSP, ruang lingkup biaya/tariff disajikan pada tabel berikut ini :

Tabel 9. Ruang Lingkup : Biaya / Tarif

\begin{tabular}{ccccc}
\hline \multirow{2}{*}{ NO } & \multirow{2}{*}{ Jawaban } & Skor & \multicolumn{2}{c}{ Frekuensi } \\
\cline { 4 - 5 } & & & $\mathrm{F}$ & $\%$ \\
\hline 1 & Gratis & 3 & 10 & $4.37 \%$ \\
\hline 2 & Murah & 2 & 58 & $25.33 \%$ \\
\hline 3 & Cukup Mahal & 1 & 94 & $41.05 \%$ \\
\hline 4 & Mahal & & 67 & $29.26 \%$ \\
\hline & & Jumalh & 229 & $100.00 \%$ \\
\hline
\end{tabular}

Kewajaran biaya/tarif dalam pelayanan di Dinas Penanaman Modal dan Pelayanan Terpadu Satu Pintu (DPM-PTSP), responden yang menjawab tarif pelayanannya murah 41,05 persen, responden yang menjawab tarif pelayanannya gratis yaitu 29,26 persen, responden yang menjawab tarif pelayanannya cukup mahal 25,33 persen dan responden yang menjawab tarif pelayanannya sangat mahal 4,37.

5. Produk Sfesikasi Jenis Pelayanan

Produk sfesifikasi jenis pelayanan adalah hasil pelayanan yang diberikan dan diterima sesuai dengan ketentuan yang telah ditetapkan.Produk pelayanan ini merupakan hasil dari setiap spesifikasi jenis pelayanan. Dari hasil analisis diperoleh rata-rata skor sebesar 2,862 berada pada interval 2,51 s.d 3,25 kategori “ Baik “. Dengan demikian kepuasan masyarakat pengguna layanan DPM-PTSP, ruang lingkup produk spesifikasi berada pada kategori baik.

Adapun hasil jawaban kuesioner kepuasan masyarakat pengguna layanan DPM-PTSP Kab.Kepl.Talaud, ruang lingkup produk spesifikasi jenis pelayanan dapat disajikan pada tabel berikut ini :

Tabel 10. Ruang Lingkup : Produk Spesifikasi Jenis Pelayanan

\begin{tabular}{|c|c|c|c|c|}
\hline \multirow{2}{*}{ NO } & \multirow{2}{*}{ Jawaban } & \multirow{2}{*}{ Skor } & \multicolumn{2}{|c|}{ Frekuensi } \\
\hline & & & $\mathrm{F}$ & $\%$ \\
\hline 1 & Sangat Sesuai & 4 & 4 & $1.75 \%$ \\
\hline 2 & Sesuai & 3 & 25 & $10.92 \%$ \\
\hline 3 & Kurang Sesuai & 2 & 198 & $86.46 \%$ \\
\hline 4 & Tidak Sesuai & 1 & 2 & $0.87 \%$ \\
\hline \multicolumn{3}{|c|}{ Jumlah } & 229 & $100.00 \%$ \\
\hline
\end{tabular}


Kewajaran biaya/tarif dalam pelayanan di Dinas Penanaman Modal dan Pelayanan Terpadu Satu Pintu (DPM-PTSP), responden yang menjawab tarif pelayanannya murah 41,05 persen, responden yang menjawab tarif pelayanannya gratis yaitu 29,26 persen, responden yang menjawab tarif pelayanannya cukup mahal 25,33 persen dan responden yang menjawab tarif pelayanannya sangat mahal 4,37 persen.

6. Kompetensi Pelaksana

Kompetensi Pelaksana adalah kemampuan yang harus dimiliki oleh pelaksana meliputi pengetahuan, keahlian, keterampilan, dan pengalaman. Dari hasil analisis diperoleh rata-rata skor sebesar 2,862 berada pada interval skor 2,51 - 3,25 kategori "Baik". Dengan demikian kepuasan masyarakat pengguna layanan DPM-PTSP, ruang lingkup kompetensi pelaksana berada pada kategori baik.

Adapun hasil jawaban kuesioner kepuasan masyarakat pengguna layanan DPM-PTSP, ruang lingkup kompetensi pelaksana disajikan pada tabel berikut ini.

Tabel 11. Ruang Lingkup : Kompetensi Pelaksana

\begin{tabular}{clccr}
\hline \multirow{2}{*}{ NO } & \multirow{2}{*}{ Jawaban } & \multirow{2}{*}{ Skor } & \multicolumn{2}{c}{ Frekuensi } \\
\cline { 4 - 5 } & & 4 & 1 & \multicolumn{2}{c}{ F } \\
\hline 1 & Sangat Kompeten & 3 & 26 & $0.44 \%$ \\
\hline 2 & Kompeten & 2 & 197 & $85 \%$ \\
\hline 3 & Kurang Kompeten & 1 & 5 & $2.18 \%$ \\
\hline 4 & Tidak Kompeten & Jumalh & 229 & $100.00 \%$ \\
\hline
\end{tabular}

Kompetensi/Kemampuan Petugas dalam Pelayanan di Dinas Penanaman Modal dan Pelayanan Terpadu Satu Pintu (DPM-PTSP), persentase petugas yang kompeten yaitu 86,03 persen, petugas yang kurang kompeten 11, 35 persen, petugas yang sangat kompeten 2, 18 persen dan petugas yang tidak kompeten 0,44 persen.

7. Perilaku Pelaksana

Perilaku pelaksana adalah sikap petugas dalam memberikan pelayanan. Dari hasil analisis diperoleh rata-rata skor sebesar 2,973 berada pada interval skor 2,51 s.d 3,25 kategori "baik". Dengan demikian kepuasan masyarakat pengguna layanan DPMPTSP, ruang lingkup perilaku pelaksana berada pada kategori baik.

Adapun hasil jawaban kuesioner kepuasan masyarakat pengguna layanan DPM-PTSP, ruang lingkup perilaku pelaksana disajikan pada tabel berikut ini.

Tabel 12. Ruang Lingkup : Perilaku Pelaksana

\begin{tabular}{c|l|c|c|c}
\hline \multirow{2}{*}{ NO } & \multirow{2}{*}{ Jawaban } & \multirow{2}{*}{ Skor } & \multicolumn{2}{|c}{ Frekuensi } \\
\cline { 3 - 5 } & & $\mathrm{F}$ & $\%$ \\
\hline 1 & Sangat Ramah & 4 & 2 & $0.87 \%$ \\
\hline 2 & Sopaan dan Ramah & 3 & 10 & $4.37 \%$ \\
\hline 3 & Kurang Ramah & 2 & 209 & $91.27 \%$ \\
\hline 4 & Tidak Ramah & 1 & 8 & $3.49 \%$ \\
\hline \multicolumn{2}{c}{ Jumlah } & 229 & $100.00 \%$ \\
\hline
\end{tabular}

Perilaku Petugas dalam Pelayanan Terkait Kesopanan dan Keramahan di Dinas Penanaman Modal dan Pelayanan Terpadu Satu Pintu (DPM-PTSP), petugas yang sopan dan ramah 91,27 persen, petugas yang kurang sopan dan kurang ramah 4,37 
persen, petugas yang sangat sopan dan sangat ramah 3, 49 persen dan petugas yang tidak sopan dan tidak ramah 0,87 persen.

8. Sarana dan Prasarana

Sarana adalah segala sesuatu yang dapat dipakai sebagai alat dalam mencapai maksud dan tujuan tata cara pelaksanaan penanganan dan tindak lanjut. Prasarana adalah segala sesuatu yang merupakan penunjang utama terselenggaranya suatu proses ( usaha, pembangunan, proyek ). Sarana digunakan untuk benda yang bergerak ( Komputer, mesin ) dan prasarana untuk benda yang tidak bergerak ( Gedung ). Dari hasil analisis diperoleh rata-rata skor sebesar 2,414 berada pada interval skor 1,76 s.d 2,50 kategori " kurang baik".

Adapun hasil jawaban kuesioner kepuasan masyarakat pengguna layanan DPM-PTSP, ruang lingkup Sarana dan Prasarana disajikan pada tabel berikut ini :

Tabel 13. Ruang Lingkup : Sarana dan Prasarana

\begin{tabular}{|c|c|c|c|c|}
\hline \multirow{2}{*}{ NO } & \multirow{2}{*}{ Jawaban } & \multirow{2}{*}{ Skor } & \multicolumn{2}{|c|}{ Frekuensi } \\
\hline & & & $\mathrm{F}$ & $\%$ \\
\hline 1 & Sangat Baik & 4 & 6 & $2.62 \%$ \\
\hline 2 & Baik & 3 & 132 & $57.64 \%$ \\
\hline 3 & Cukup & 2 & 85 & $37.12 \%$ \\
\hline 4 & Buruk & 1 & 6 & $2.62 \%$ \\
\hline \multicolumn{3}{|c|}{ Jumlah } & 229 & $100.00 \%$ \\
\hline
\end{tabular}

Kualitas Sarana dan Prasarana di Dinas Penanaman Modal dan Pelayanan Terpadu Satu Pintu (DPM-PTSP), responden yang menjawab kualitas sarana dan prasarananya cukup yaitu 57,64 persen, kualitas sarana dan prasarananya baik 37, 12 persen, kualitas sarana dan prasarananya sangat baik dan kualitas sarana dan prasarananya buruksebesar 2,62 persen.

9. Penanganan Pengaduan, Saran dan Masukan

Penanganan Pengaduan, Saran dan Masukan, adalah tata cara pelaksanaan penanganan pengaduan dan tindak lanjut. Dari hasil analisis diperoleh rata-rata skor sebesar 2,584 berada pada interval skor 2,51 s.d 3,25 kategori “ Baik “. Dengan demikian kepuasan masyarakat pengguna layanan DPM-PTSP, ruang lingkup penanganan pengaduan, saran dan masukan disajikan pada tabel berikut ini :

Tabel 14. Ruang Lingkup : Penanganan Pengaduan, Saran dan Masukan

\begin{tabular}{cccc|c}
\hline \multirow{2}{*}{ NO Jawaban } & \multirow{2}{*}{ Skor } & \multicolumn{2}{c}{ Frekuensi } \\
\cline { 4 - 5 } & & & $\mathrm{F}$ & \multicolumn{2}{c}{$\%$} \\
\hline 1 & Dikelola dengan sangat baik & 3 & 84 & $4.80 \%$ \\
\hline 2 & Berfungsi Kurang Maksimal & 2 & 71 & $33.62 \%$ \\
\hline 3 & Ada tetapi tidak berfungsi & 1 & 57 & $24.89 \%$ \\
\hline 4 & Tidak Ada & & 229 & $100.00 \%$ \\
\hline
\end{tabular}

Penanganan Pengaduan Pengguna Layanan di Dinas Penanaman Modal dan Pelayanan Terpadu Satu Pintu (DPM-PTSP), responden yang menjawab Penanganan Pengaduan Pengguna layanan tidak ada yaitu 36,68 persen, fasilitas Penanganan Pengaduan Pengguna layanan yang berfungsi kurang maksimal 33, 62 persen, fasilitas pengaduan 
pengguna layanan dikelola dengan baik 24,89 persen dan fasilitas penanganan pengaduan pengguna layanan ada tapi tidak berfungsi 4,80 persen.

\section{Pembahasan}

Faktor timbulnya berbagai masalah yang ada dilapangan dalam kegiatan Survey IKM dapat bermacam-macam. Namun berdasarkan pengamatan dan evaluasi yang diperoleh, penyebab yang dianggap paling dominan terhadap timbulnya masalah tersebut dapat disajikan uraian sebagai berikut :

1. Masalah masyarakat (Responden) sebagian tidak bersungguh- sungguh dalam memberikan pendapatnya (tidak obyektif). Hal ini disebabkan karena kurangnya pemahaman responden akan pentingnya hasil survey kepuasan masyarakat .

2. Pelaksanaan survey kepuasan masyarakat ini, baru pertama kali dilakukan di Dinas Penanaman Modal dan Pelayanan Terpadu Satu Pintu sehingga masih ada responden yang belum memahami kuesioner yang disampaikan sehingga harus dibacakan dan diberikan penjelasan maksud kuesionernya.

Berdasarkan analisa permasalahan tersebut diatas maka alternative pemecahan permasalahannya adalah sebagai berikut :

1. Perlunya diadakan sosialisasi kepada masyarakat tentang pentingnya survey indeks kepuasan masyarakat (IKM) dalam upaya meningkatkan kualitas pelayanan untuk mewujudkan pelayanan prima ( publik service ) dalam arti memenuhi harapan dan kebutuhan baik bagi pemberi maupun penerima pelayanan.

2. Diperlukannya konsisten para penyelenggara pelayanan publik disemua sector untuk terus menerus meningkatkan kemampuannya, ketrampilan, kenyamanan, keamanan dan kelengkapan sarana prasarana pendukung dan mampu melaksanakan pelayanan publik secara transparan dan akuntabel.

Perlunya peningkatan SDM Aparatur melalu seminar-seminar, pelatihan dan diklat teknis tentang pelayanan publik dalam upaya mendukung pelaksanaan survey indeks kepuasan masyarakat

\section{KESIMPULAN DAN SARAN}

Keberhasilan pelaksanaan Survey Kepuasan Masyarakat (SKM) sebagai upaya untuk meningkatkan kualitas pelayanan pada Dinas Penanaman Modal dan Pelayanan Terpadu Satu Pintu Kabupaten Kepulauan Talaud.Komitmen dan kesungguhan para pelaksana dalam hal ini aparatur di Dinas Penanaman Modal dan Pelayanan Terpadu Satu Pintu Kabupaten Kepulauan Talaud sangat diharapkan.Dan tentunya tidak terlepas dari pembinaan serta perhatian dari unsur pimpinan daerah serta masyarakat luas sebagai objek pelayanan. Untuk itu, peningkatan sumber daya manusia (SDM), Sarana dan Prasarana adalah hal yang tidak dapat dipisahkan dalam rangka meningkatkan citra pelayanan, sehingga pelaksanaan pelayanan perizinan terpadu satu pintu berjalan dengan mudah, cepat dan transparan.

\section{Kesimpulan}

Kesimpulan yang didapatkan dari hasil pelaksanaan Survey Kepuasan Masyarakat(SKM)adalah sebagai berikut : 
1. Tingkat kepuasan masyarakat pengguna layanan Dinas Penanaman Modal dan Pelayanan Terpadu satu pintu Kabupaten Kepulauan Talaud hasil SKM adalah 89,96atau berada pada kategori B (Baik).

2. Masukan dari masyarakat secara kualitatif melalui pendapat masyarakat dalam memperoleh pelayanan dari aparatur penyelenggara pelayanan di Dinas Penanaman Modal dan Pelayanan Terpadu Satu Pintu Kabupaten Kepulauan Talaud meningkatkan pelayanan yang diselenggarakannya.

3. Berdasarkan survey yang dilakukan Target yang dicapai untuk nilai Indeks Kepuasan Masyarakat (IKM) adalah 70,08 berada pada kategori kurang baik

4. Untuk bisa mewujudkan pelaksanaan pelayanan prima diperlukan komitmen untuk melaksanakan Transparansi dan Akuntabilitas, baik oleh pengambilan keputusan (Top Manejer ), Pimpinan Unit pelaksana pelayanan publik, untuk selalu berupaya

5. memberikan pelayanan secara cepat, tepat, Murah, terbuka, sederhana, dan mudah dilaksanakan serta tidak diskriminatif. Disisi lain masyarakat khususnya pelaku usaha diharapkan ikut membantu dalam arti melengkapi syarat berkas-berkas layanan serta tidak bersifat apatis terhadap upaya-upaya peningkatan pelayanan.

6. Untuk menciptakan pelayanan yang baik, IKM ini akan terus dilakukan guna melihat sejauh mana tingkat kepuasan masyarakat terhadap pelayanan perizinan yang kita berikan. Dinas Penanaman Modal dan Pelayanan Terpadu Satu Pintu Kabupaten Kepulauan Talaud akan menargetkan kegiatan ini setiap 6 bulan sekali.

\section{Saran}

Pemerintah Kabupaten KepulauanTalaud diharapkan membentuk Tim Survey IKM atau menunjuk/ bekerjasama dengan unit independen untuk melaksanakan survey di unit-unit pelayanan. Dengan adanya tim yang benar-benar independen, kapabel dan mempunyai kredibilitas akan menjamin hasil survey IKM yang betul-betul Valid dan akuntabel. Langkahlangkah untuk mencapai target IKM adalah sebagai berikut :

(a) Memberikan pelatihan kepada petugas loket pendaftaran pada unit penelitian administrasi yang berkaitan dengan pelayanan

(b) Menyebarkan dan menyiapkan brosur atau leaf flat diloket pendaftaran Survey IKM akan terus akan terus dilakukan secara berkesinambungan

Dengan pembentukan tim survey IKM ini, diharapkan pelayanan pada Dinas Penanaman Modal dan Pelayanan Terpadu Satu Pintu Kabupaten Kepulauan Talaud kedepan akan semakin baik ( menyempurnakan kekurangan kekurangan yang ada ).

\section{DAFTAR RUJUKAN}

Bungin, Burhan. 2011. Metodologi Penelitian Kuantitatif: Komunikasi, Ekonomi, Dan Kebijakan Publik Serta Ilmu-ilmu Sosial Lainnya. Jakarta: Kencana.

Coast, David and Eleanor Passmore. 2008. Public Value: The Next Steps In Public Service Reform. London: The Work Foundation.

Cole, Martin and Gres Parston. 2006. Unlocking Public Value: A New Model For Achieving High Performance In Public Service Organizations. Canada: WILEY.

Complaint Satisfaction. Barbara Lewis and Ton Van Der Wiele. 12(3): 176. 
Hardiyansyah. 2011. Kualitas Pelayanan Publik: Konsep, Dimensi Indikator dan Implementasinya. Yogyakarta: Gava Media.

Edvardsson, Bo. 2005. Service Quality: Beyond Cognitive Assessment. Anders Gustafsson and Bo Edvardsson. 15(2): 127-128. Stauss, Bernd. 2002. The Dimensions Of Complaint Satisfaction: Process And Outcome Complaint Satisfaction Versus Cold Fact And Warm Act

Keputusan Menteri Pendayagunaan Aparatur Negara dan Reformasi birokrasi Republik Indonesia Nomor: 14 tahun 2017 Tentang Pedoman Penyusunan Survei Kepuasan Masyarakat Unit Penyelenggaraan Pelayanan Publik

Lingwood, Robert G. 1999. A Handbook for Measuring Customer Satisfaction and Service Quality. Washington, D.C: TCRP Report 47. Moenir, H.A.S. 2010. Manajemen Pelayanan Umum di Indonesia. Jakarta: Bumi Aksara.

Napitupulu, Paimin. 2007. Pelayanan Publik dan Customer Satisfaction. Bandung: PT Alumni..

Purwanto, Erwan Agus dan Dyah Ratih Sulistyastuti. 2011. Metode Penelitian Kuantitatif Untuk Administrasi Publik Dan Masalah- Masalah Sosial. Yogyakarta: Gava .

Rahmayanty, Nina. 2010. Manajemen Pelayanan Prima. Yogyakarta: Graha Ilmu.

Ratminto dan Atik Septi Winarsih. 2008. Manajemen Pelayanan: Pengembangan Model Konseptual, Penerapan Citizen's Charter dan Standar Pelayanan Minimal. Yogyakarta: Pustaka Belajar.

Safroni, M. Ladzi. 2012. Manajemen dan Reformasi Pelayanan Publik dalam Konteks Birokrasi Indonesia: Teori, Kebijakan, dan Implementasi. Malang: Aditya Media Publishing. Sinambela, Lijan Poltak dkk. 2011. Reformasi Pelayanan Publik: Teori, Kebijakan, dan Implementasi. Jakarta: Bumi Aksara.

Sugiyono. 2011. Metode Penelitian Kuantitatif, Kualitatif Dan R\&D. Bandung: Alfabeta. Tjiptono, Fandy. 2002. Prinsip-prinsip Total Quality Servive (TQS). Yogyakarta: Andi. 